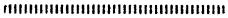 \\ 論文

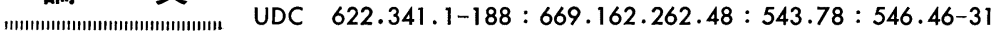 \\ 自溶性ペレットの各種冶金性状におよぼす $\mathrm{MgO}$ 添加の影響*
}

\author{
土屋 脩**. 杉山 健 ${ }^{* *} \cdot$ 小野田守**. 藤田勇雄 ${ }^{* * *}$
}

\section{Effect of MgO-component on Various Metallurgical Properties of Self-fluxed Pellets}

Osamu Tsuchiya, Takeshi Sugryama, Mamoru Onoda, and Isao Fujita

Synopsis :

Effects of $\mathrm{MgO}$ component on metallurgical properties of fluxed pellets with $0.5,1.5$ and 2.0 of $\mathrm{CaO} / \mathrm{SiO}_{2}$, were evaluated from a laboratory-scale reduction test, high temperature reduction test, and softening test under load with one pellet.

The results are as follows :

(1) Reduction degree at $900^{\circ} \mathrm{C} \sim 1100^{\circ} \mathrm{G}$ increases with the increase of $\mathrm{MgO}$ contents in pellets with 0.5 of $\mathrm{CaO} / \mathrm{SiO}_{2}$, and with $1.5 \sim 2.0$ of $\mathrm{CaO} / \mathrm{SiO}_{2}$ indurated at $1200^{\circ} \mathrm{C}$. However that of the latter pellet indurated at $1250 \sim 1300^{\circ} \mathrm{G}$ does not change or decreases slightly.

(2) Swelling index of pellets with 0.5 of $\mathrm{CaO} / \mathrm{SiO}_{2}$ shows higher values of $20 \sim 45 \%$ at $1 \sim 2 \%$ of $\mathrm{MgO}$ contents, and that of pellets with $\mathrm{MgO} 4 \%$ lowers to $10 \sim 15 \%$. The index of pellets with 1.5 of $\mathrm{CaO} /$ $\mathrm{SiO}_{2}$ decreases with the increase of $\mathrm{MgO}$ contents.

(3) Softening properties during reduction test under load areimproved with the addition of $\mathrm{MgO}$ component, especially with more than $4 \% \mathrm{MgO}$ than $2 \% \mathrm{MgO}$ in case of 0.5 and 1.5 of $\mathrm{CaO} / \mathrm{SiO}_{2}$ respectively, because magnesio-ferrite and/or $\mathrm{MgO}$-contained calcium ferrite phases with a better softening property are generated in pellets by adding $\mathrm{MgO}$.

High temperature properties are better in the pellets that showed higher forming temperatures of preliminary liquidus slag from DTA curves of wüstite powder of pellets.

\section{1. 緒言}

石灰源としてドロマイトを添加した自溶性ペレットの 性状に関する報告は古くからあり，また最近では高温性 状の改善に着目してドロマイトがペレットへ添加されて いる。これによれば，ペレット中結合組織としてマグネ シオフェライト相の新たな生成の特徵が示され，また低 温遭元崩壊性の低減特よび軟化・溶融温度の上昇が述べ られている1) 14).さらには, 酸性ペレットの高温性状改 善にマグネサイトの添加が有効であることが確認されて (る15)16).

著者等は自溶性ペレットの製造時に拈ける適正なる溶 剂の配合および焼成条件を把握するための一連の研究と して，石灰石添加によるペレットの自溶性化過程におけ る各種冶金性状と結合組織との関連および $\mathrm{MgO}$ 含有ぺ レットの鉱物組織変化について報告した17～19)．本論文 はこれらの研究に引き続き，自溶性ペレットの治金性状
に持よぼす $\mathrm{MgO}$ 成分の影響について検討したもので， $\mathrm{CaO} / \mathrm{SiO}_{2}$ 比が $0.5,1.5,2.0$ において $\mathrm{MgO}$ 量を 0 〜 4\% ( 8\%) まで変更した際のペレットの常温性状, 低温還元性状和よび高温還元・軟化性状の変化を明らか にしたものである。

\section{2. 実 験 方 法}

供試原料の種類, 粒度, 化学組成, ペレットの製造法 は既報17) 19〉 と同様であるので省略する。

焼成ペレットの治金性状は，常温性状として圧潰強度 気孔率を，低温還元性状として還元温度 $900 ， 1000$ お よび $1100^{\circ} \mathrm{C}$ における $1 \mathrm{~h}$ 還元後の還元率およびふくれ 指数を, 高温性状として温度 $1250^{\circ} \mathrm{C}$ に打ける高温還元 率および単一ペレットを用いての荷重軟化・溶融試験か ら得た温度一収縮率曲線をもとに $20 \%$ 収縮率を示した時 の温度で示す軟化開始温度, $60 \%$ 収縮率を示した時の温 度で示す $60 \%$ 軟化温度および最終軟化曲線を収縮率

\footnotetext{
* 昭和 51 年 4 月本会講演大会にて発表 昭和 55 年 3 月 21 日受付 (Received Mar. 21，1980)

** (株) 神戸製鋼所中央研究所 (Central Research Laboratory, Kobe Steel, Ltd., 1-3-18 Wakinohama-cho Fukiai-ku Kobe 651)

*** (株) 神戸製鋼所中央研究所 理博 (Central Research Laboratory, Kobe Steel, Ltd.)
} 
$100 \%$ に外插した時の温度で示す溶融温度を求めた．以 上の各治金性状の測定方法については既報17)18)を参照さ れたい。

\section{3. 実 験 結 果}

\section{1 常温性状}

Fig. 1 は供試ペレットの $\mathrm{MgO}$ 含有量による圧潰強 度の変化を各 $\mathrm{CaO} / \mathrm{SiO}_{2}$ 此抢よび焼成温度別に示した ものである。この図から明らかなように，自溶性ペレッ トへの $\mathrm{MgO}$ 添加により区潰強度に変化がないか，また は低下する傾向を示し， $1200^{\circ} \mathrm{C}$ の低温度焼成および $1300^{\circ} \mathrm{C}$ の高温度焼成において 低下の度合が著しく, $1250^{\circ} \mathrm{C}$ に打いてはほぼ同一の強度を示す.

以上の現象を前報 ${ }^{19)}$ の鉣物組織の変化を参照して検討 する。低温度焼成では $\mathrm{MgO}$ 添加により $\mathrm{MgO}$ を含有 した低塩基度スラグまたはカルシウムフェライトが生成 し，この相は $\mathrm{MgO}$ を含有しない両相に比べて融点が高 いためか，液相焼結反応が進行しにくくなり，鉱粒間の 結合を弱めるものと推察される. しかしマグネシオフェ ライトを生成すると若干強度を回復しており，これは $\mathrm{FeO}-\mathrm{Fe}_{2} \mathrm{O}_{3}-2 \mathrm{CaO} \cdot \mathrm{SiO}_{2}$ 三元系状態図 ${ }^{20)}$ から推察され るよらに焼結過程で低融点スラグが生成し，これが鈗粒 間結合を強める働きをする。高温度焼成においては， 低, 中または高塩基度スラグが生成し，このスラグの一部 は松野21)の実験結果からガラス質スラグであると推定さ れる，ガラス質スラグは冷却時に微細クラックを生じ強 度を低下する原因となる，またへマタイトのマグネシオ フェライトへの変態過程で, 格子変態に伴ら内部残留応 力の蓄積があるものと考光られ, $\mathrm{MgO}$ 添加量の多い注 どこの応力も大きい，従つてこれら両者の相乗作用によ り，冷却時に構造上の欠陥が拡大されてより強度を低下 する傾向にあるものと考劣られるが推論の域を出ない.

Fig. 2 に全気孔率および開気孔率の $\mathrm{MgO}$ に対する 変化を示す. $\mathrm{CaO} / \mathrm{SiO}_{2}$ 比が 0.5 のペレットでは $\mathrm{MgO}$

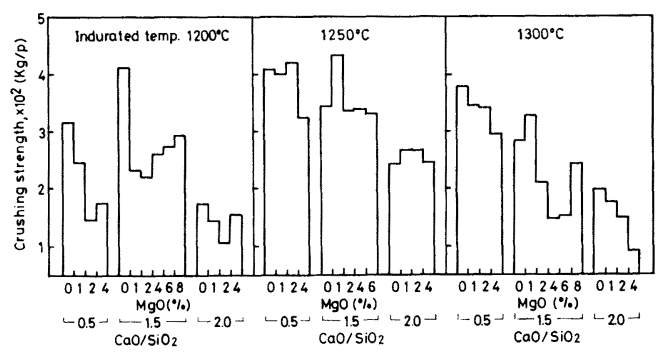

Fig. 1. Effect of $\mathrm{MgO}$ contents on crushing strengh of sampled pellets with various $\mathrm{CaO} / \mathrm{SiO}_{2}$ ratios and indurated temp.

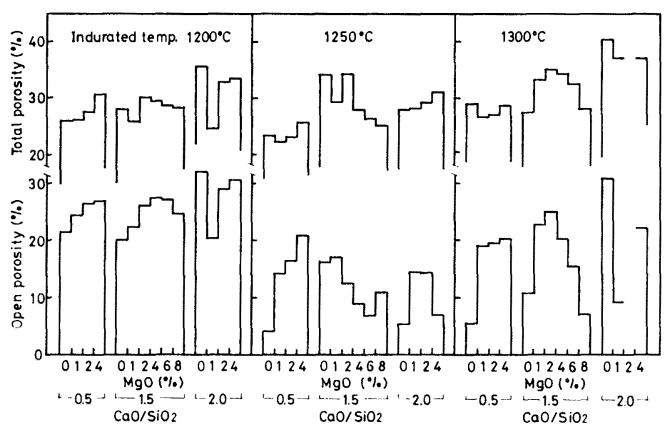

Fig. 2. Effect of $\mathrm{MgO}$ contents on total- and open porosity of sampled pellets with various $\mathrm{CaO} / \mathrm{SiO}_{2}$ ratios and indurated temp.

量の増加に伴つて各温度で焼成されたペレットとも全・ 開気孔率とも増大する。 $\mathrm{CaO} / \mathrm{SiO}_{2}$ 比が 1.5 のペレッ トでは, 所定の $\mathrm{MgO}$ 量に極大を持つ全・開気孔率の変 化が示され，その $\mathrm{MgO}$ 量は焼成温度によりわずかに異 なるが $\mathrm{MgO} 2$ 2\% である. $\mathrm{CaO} / \mathrm{SiO}_{2}$ 比が 2.0 のペ レットでは焼成温度 $1200^{\circ} \mathrm{C}$ および $1300^{\circ} \mathrm{C}$ に拈いて $\mathrm{MgO} 1 \%$ で両気孔率とも著しく低下寸る特徴があり, 焼成温度 $1250^{\circ} \mathrm{C}$ では全気孔率は $\mathrm{MgO}$ 量の増加に伴 つて増大して拈り，開気孔率は $\mathrm{MgO} 1$ 1 2\% に拈いて 極大を示す.

これら気孔率変化の理由は更に詳細なる検討を要する が，定性的には次のように説明される．自溶性ペレット の焼結反応は液相焼結反忘が支配的であり，焼成過程で の主に液相生成温度により気孔率は变化する。 $\mathrm{MgO}$ 添 加によりペレット中に出現する鉱物組織は $\mathrm{MgO}$ を含有 するスラグ， $\mathrm{MgO}$ を約 $3 \%$ 含有するカルシウムフェラ イトおよびマグネシオフェライトに特徴づけられる ${ }^{19)}$. したがつて,スラグおよびカルシウムフェライトへ $\mathrm{MgO}$ を含有することにより各鉱物相の溶融する温度がどのよ らに変化するかが重要となる，これに関する物性值は文 献等に報告されてないが， $\mathrm{MgO}$ を含有することにより 各相の上記温度は上.昇するものと考えられ，またマグネ シオフェライトは前述のごとく低融点スラグの生成を促 進するとの推定から，低・中塩基度スラグおよびカルシ ウムフェライトは $\mathrm{MgO}$ を含有することにより気孔率を 増大し，マグネシオフェライトは低下する働きを持つ. すなわち，これら主に 3 鉱物相の生成割合が焼成温度, 塩基度および $\mathrm{MgO}$ 量により变化し，上述の気孔率の 変化が示されたものであろら。しかし $\mathrm{CaO} / \mathrm{SiO}_{2}$ 比が 2.0 で $\mathrm{MgO} 1 \%$ 含有するペレットの気孔率が極小值を 示すことは説明できない.

\section{$3 \cdot 2$ 低温㯰元性状}




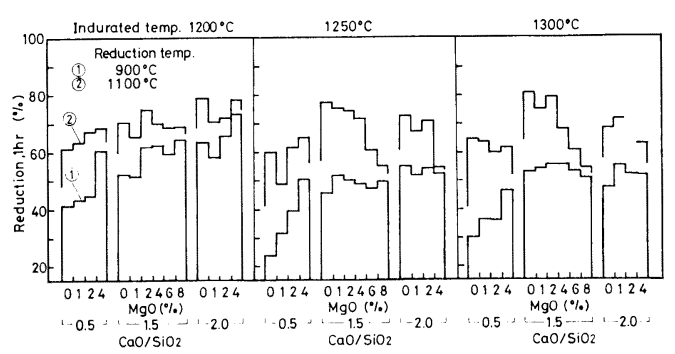

Fig. 3. Effect of $\mathrm{MgO}$ contents on reduction degree of sampled pellets with various $\mathrm{CaO} / \mathrm{SiO}_{2}$ ratios and indurated temp.

Fig. 3 に供試ペレットの還元温度 900 および 1100 ${ }^{\circ} \mathrm{C}$ に持ける還元率の $\mathrm{MgO}$ 量による变化を示す。焼成 温度 $1200^{\circ} \mathrm{C}$ においては各 $\mathrm{CaO} / \mathrm{SiO}_{2}$ 比のペレットと も $\mathrm{MgO}$ 量の増加に伴つて還元率を増大する傾问にあ り，その増加度合は $\mathrm{CaO} / \mathrm{SiO}_{2}$ 比が 0.5 および還元温 度 $900^{\circ} \mathrm{C}$ に扔いて著しい。焼成温度 $1250^{\circ} \mathrm{C}$ に打いて は, $\mathrm{CaO} / \mathrm{SiO}_{2}$ 比が 0.5 のペレットは焼成温度 1200 ${ }^{\circ} \mathrm{C}$ の場合と同様であるが， $\mathrm{CaO} / \mathrm{SiO}_{2}$ 比が $1.5 \sim 2.0$ のペレットは還元温度 $900^{\circ} \mathrm{C}$ では還元率の $\mathrm{MgO}$ 量に よる変化は少なく, 還元温度 $1100^{\circ} \mathrm{C}$ では $\mathrm{MgO}$ 量の 増加に伴つて低下する傾向にある。焼成温度 $1300^{\circ} \mathrm{C}$ に 扣いては，還元温度 $900^{\circ} \mathrm{C}$ の場合は各 $\mathrm{CaO} / \mathrm{SiO}_{2}$ 比の ペレットとも焼成温度 $1250^{\circ} \mathrm{C}$ と同一の傾向を示し，還 元温度 $1100^{\circ} \mathrm{C}$ の場合は $\mathrm{MgO}$ 量の増大に伴つて還元 率を低下する.

ペレットへ $\mathrm{MgO}$ を添加することによりマグネシオフ エライトが生成する ${ }^{919)}$. 佐々木ら ${ }^{22)}$ および杉山ら 結果からマグネシオフェライト生成量が増加しても還元 性はほとんど変化しないものと考皇られる。一方 Fig.

2 および Fig. 3 より $\mathrm{MgO}$ 添加に伴ら父孔率变化と還 元率の変化には，密接なる関係があるとみなされるの で，還元性は焼成時の気孔形成状況に大きく影響される ものと考えられる. 次にふくれ指数の $\mathrm{MgO}$ 添加による 変化をFig. 4 に示す.

$\mathrm{CaO} / \mathrm{SiO}_{2}$ 比が 0.5 のペレットに拈いては, $\mathrm{MgO} 1$ 〜2\% 含有ペレットでは $\mathrm{MgO}$ 無添加ペレットに比べて 高い值の 20 ～ $45 \%$ のふくれ指数を示す場合が多く， $\mathrm{MgO} \mathrm{4 \%}$ と高配合に扮いて初めてふくれ指数 10～15\% の值が示される.

$\mathrm{CaO} / \mathrm{SiO}_{2}$ 比が 1.5 2.0 のペレットはふくれ指数が 最大で $14 \%$ であり非常に低い值を示す. $\mathrm{MgO}$ の添加 により $\mathrm{CaO} / \mathrm{SiO}_{2}$ 比が 1.5 のペレットでは $\mathrm{MgO}$ 量の 増加に伴い低下を示し, $\mathrm{CaO} / \mathrm{SiO}_{2}$ 比が 2.0 のペレット では $\mathrm{MgO}$ 1〜2\% まではふくれ指数が変わらないかま

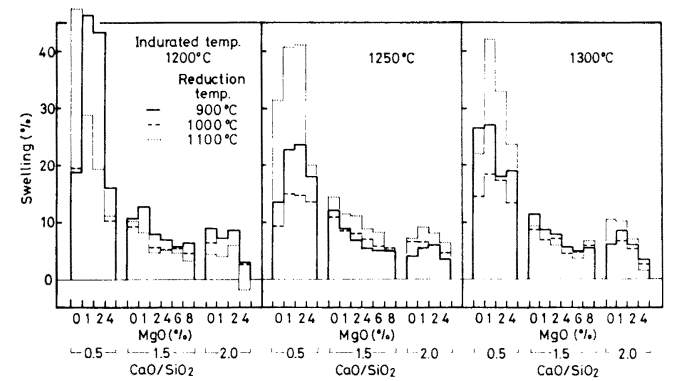

Fig. 4. Effect of $\mathrm{MgO}$ contents on swelling value of sampled pellets with various $\mathrm{CaO} / \mathrm{SiO}_{2}$ ratios and indurated temp.

たはわずかに高くなるが， $\mathrm{MgO}$ 2〜4\% では低下する. $\mathrm{MgO}$ はマグネシオフェライトの牛成を促進し，したが つてへマタイト量が減少するためふくれ指数を低下す る效果を有するものと考元られる。前報年から， $\mathrm{CaO}$ $\mathrm{SiO}_{2}$ 比が 0.5 のペレットでは久ラグ相中にも $\mathrm{MgO}$ 成 分はかなり分配されるためマグネシオフェライトの生成 は焼成温度 $1250^{\circ} \mathrm{C}$ の湯合 $\mathrm{MgO} 4 \%$ で初めて起こつ ている、したがつて，このペレットは $\mathrm{MgO} 4 \%$ におい てふくれ指数が低下する. しかし $\mathrm{MgO} 4 \%$ でも還元温 度 $900^{\circ} \mathrm{C}$ では $14 \%$ 以下のふくれ指数は得られない.

\section{3 高温性状}

\section{$3 \cdot 3 \cdot 1$ 高温還元性状}

Fig. 5 に高温還元試験により得た，供試ペレットの還 元温度 $1250^{\circ} \mathrm{C}$ における $1.5 \mathrm{~h}$ 後の高温還元率および高 温還元試験前後の体積収縮率の $\mathrm{MgO}$ 含有㫣による变化 を示す.

$\mathrm{CaO} / \mathrm{SiO}_{2}$ 比が 0.5 のペレットの高温還元率は, 焼 成温度 $1200 ， 1250$ および $1300^{\circ} \mathrm{C}$ に扣いてそれぞれ ペレット中 $\mathrm{MgO}$ 童 2,1 および $2 \%$ において極小值を 持つ変化を示し, $\mathrm{MgO} 4 \%$ において著しく改善されて 高温還元率 $50 \sim 60 \%$ の值を持つ. $\mathrm{CaO} / \mathrm{SiO}_{2}$ 比が 1.5 のペレットでは $\mathrm{MgO} 1 \%$ でわずかに低い值を示した後 改善され， $\mathrm{MgO} 2 \sim 8 \%$ で高温還元率 80 90\% と高い 值を示す。 $\mathrm{CaO} / \mathrm{SiO}_{2}$ 此が 2.0 のペレットにおいては 高温還元㳯 85～97\% と高いレベルにある. 高温還元式 験後の収縮率は $\mathrm{MgO}$ 量の増加に伴つて低下を示し,

$\mathrm{CaO} / \mathrm{SiO}_{2}$ 比の高いほど収縮率は低い值を示す.

以上の高温還元率の変化の理由については, 4.3 項に おいて説明する.

Fig. 6 は高温還元率と $(\mathrm{CaO}+\mathrm{MgO}) / \mathrm{SiO}_{2}$ 比との関 係を示したものである. $(\mathrm{CaO}+\mathrm{MgO}) / \mathrm{SiO}_{2}$ 比が 0.7〜 1.0 で約 $12 \sim 24 \%$ の極小值を示した後 $(\mathrm{CaO}+\mathrm{MgO}) /$ $\mathrm{SiO}_{2}$ 比が 1.5 付近から急激に高温還元率は増大し，こ 


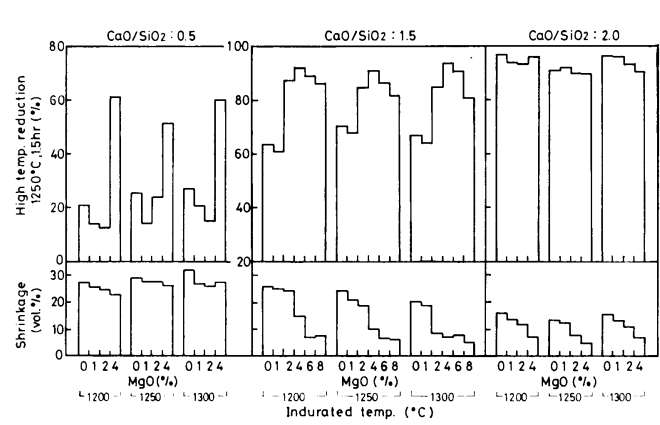

Fig. 5. Effect of $\mathrm{MgO}$ contents on reduction degree and shrinkage value by high temp. reduction test at $1250^{\circ} \mathrm{C}$, of sampled pellets with various $\mathrm{CaO} / \mathrm{SiO}_{2}$ ratios and indurated temp.

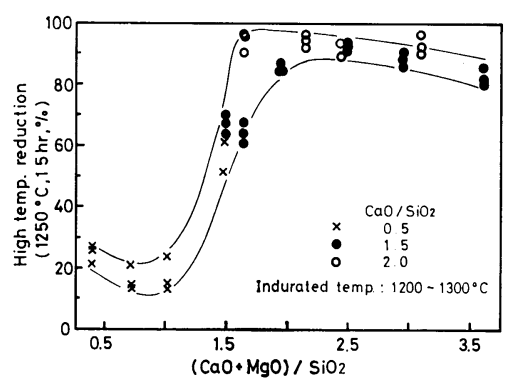

Fig. 6. Relation between reduction degree by high temp. reduction test at $1250^{\circ} \mathrm{C}$ and $(\mathrm{CaO}+\mathrm{MgO}) / \mathrm{SiO}_{2}$ of sampled pellets.

の比が 2.4 以上ではわずかに低下の傾向が見られるが 80\% 以上の高い高温還元率である.

3.3 .2 荷重軟化性状

Fig. 7 に荷重軟化・溶融試験により求めた，温度 $1300^{\circ} \mathrm{C}$ で焼成したペレットの収縮率一温度曲線を示す.

昇盜速度 $5^{\circ} \mathrm{C} / \mathrm{min}$ の条件下では, $\mathrm{CaO} / \mathrm{SiO}_{2}$ 比が 1.5 のペレットの場合, $G, G_{1}, G_{2}, G_{4}$ 扎よび $G_{6}$ に示 されるよらに $\mathrm{MgO}$ 添加に伴、軟化挙動は改善される が，昇温速度 $10^{\circ} \mathrm{C} / \mathrm{min}$ では温度 $1240 \sim 1280^{\circ} \mathrm{C}$ の範 囲で $\mathrm{MgO} 1 \%$ 含有ペレット $\left(\mathrm{G}_{\mathbf{1}}\right)$ の軟化率が $\mathrm{MgO}$ 無 添加ペレット $(\mathrm{G})$ に比べて若干の増大が示され，また昇 温速度 $20^{\circ} \mathrm{C} / \mathrm{min}$ では $\mathrm{MgO} 1 \%\left(\mathrm{G}_{1}\right)$ と $\mathrm{MgO}$ 無添 加ペレット $(\mathbf{G})$ の軟化挙動はほぼ同一となつている.こ のように昇温速度が小さい場合は $\mathrm{MgO}$ 添加に伴い耐荷 重軟化性は良好となるが，急速昇温下では $\mathrm{MgO} 2 \%$ 以 上の含有により初めて，軟化開始温度が高温度側に 移 り，収縮率が小さくなり軟化性が改善される.

次に各 $\mathrm{CaO} / \mathrm{SiO}_{2}$ 比を持つペレットの荷重軟化性状 への $\mathrm{MgO}$ 量および焼成温度の影響を知るため，昇温速 度 $10^{\circ} \mathrm{C} / \mathrm{min}$ の急速昇温下で荷重軟化・溶融試験を実施

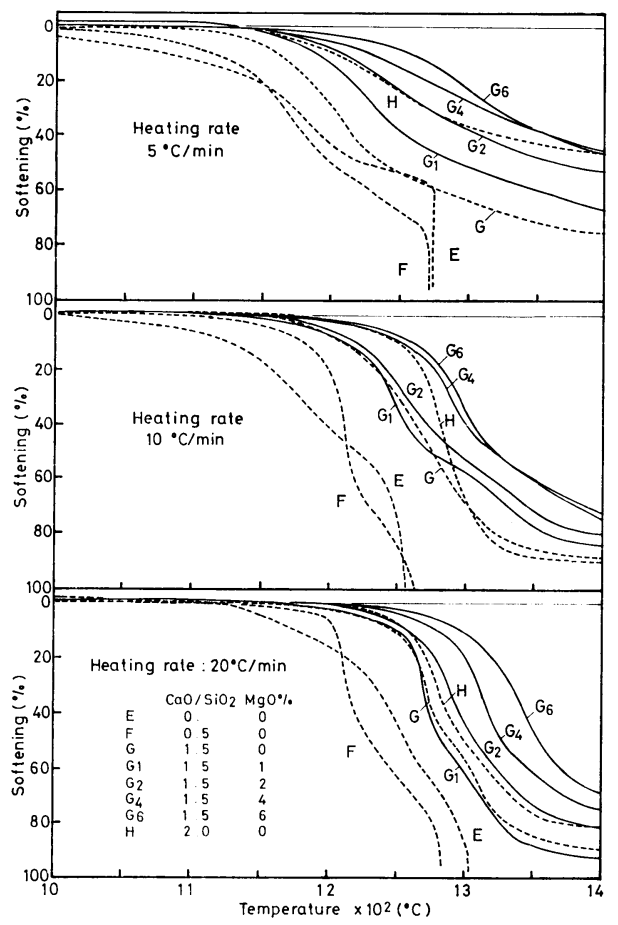

Fig. 7. Effect of $\mathrm{MgO}$ contents on softening curves by softening test under load of sampled pellets, indurated at $1300^{\circ} \mathrm{C}$.

した結果について述べる．Fig. 8 は収縮率一温度曲線か ら読又取つた軟化開始温度，60\% 軟化温度，溶融温度抒 よび $1400^{\circ} \mathrm{C}$ に打ける収縮率の各ペレットに対する值を 示したものである.

各軟化温度への $\mathrm{MgO}$ 添加の影響は, $\mathrm{CaO} / \mathrm{SiO}_{2}$ 比 が 0.5 のペレットでは $\mathrm{MgO}$ 量により種々変化して複 雑であるが， $\mathrm{CaO} / \mathrm{SiO}_{2}$ 比が 1.5 および 2.0 のペレッ トでは $\mathrm{MgO}$ 量の増加に伴つて改善される傾向にある。 $\mathrm{CaO} / \mathrm{SiO}_{2}$ 比が 0.5 のペレットにおいては軟化開始温 度は $\mathrm{MgO} 1 \%$ または $2 \%$ に極小值を持つ変化を示し， 焼成温度 $1200^{\circ} \mathrm{C}$ では $\mathrm{MgO}$ 無添加に比べて $\mathrm{MgO}$ $4 \%$ 含有することにより約 $50^{\circ} \mathrm{C}$ 軟化開始温度は上昇す る. 焼成温度 1250 および $1300^{\circ} \mathrm{C}$ では逆に低下して $\mathrm{MgO}$ 添加の 効果は得られない. $60 \%$ 軟化温度抢よび 溶融温度は焼成温度 1200 㧊よび $1300^{\circ} \mathrm{G}$ では $\mathrm{MgO}$ 量の増加に伴つて上昇するが，焼成温度 $1250^{\circ} \mathrm{C}$ では $\mathrm{MgO} 2 \%$ までは低下して $\mathrm{MgO} 4 \%$ に打いて初めて效 果が示され約 $1360^{\circ} \mathrm{C}$ の高い $60 \%$ 軟化温度を示す.

この理由は, 4.3 項の焼成ペレットに出現する鉱物根 単一の軟化・溶融挙動から，ペレットの軟化性を著しく 悪化する $\mathrm{MgO}$ を含有する低塩基度スラグと, 改善する 


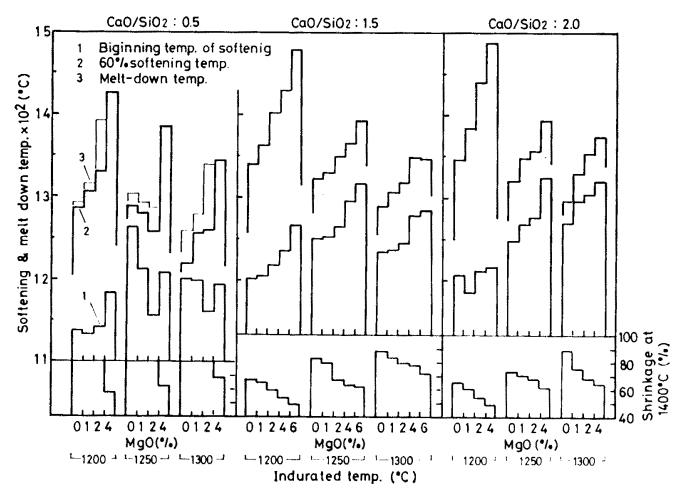

Fig. 8. Effect of $\mathrm{MgO}$ contents and indurated temp. on softening and melt-down temperature by softening test under load with $10^{\circ} \mathrm{C} / \mathrm{min}$ of heating rate.

マグネシオフェライト相の生成量が焼成温度により変化 するためと考えられる.すなわち, 焼成温度 $1200^{\circ} \mathrm{C} て ゙$ はほとんど低塩基度スラグは生成せず， $\mathrm{MgO}$ は主に未

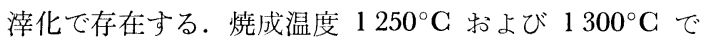
は低塩基度スラグが多量に存在するが，同時に前者の場 合は $\mathrm{MgO} 4 \%$ においてマグネシオフェライトの存在量 が低塩基度スラグのそれより多くなるのに対し，後者の 場合は推定ではあるが $\mathrm{MgO} 1 \%$ からすでにマグネシォ フェライトがより多く存在するため, 温度 $1250^{\circ} \mathrm{C} て ゙$ 焼 成した場合の及前述の $60 \%$ 軟化・溶融温度の変化に極 小值が示されたのであろらと推察される.

荷重軟化性状一の焼成温度の影響は, 焼成温度 1200 ${ }^{\circ} \mathrm{C}$ の低温度焼成した場合には $1250^{\circ} \mathrm{C}$ 以上の高温度焼 成した場合に比べて軟化開始温度は低いが，60\% 軟化温. 度は高いレベルにある. 焼成温度 $1250^{\circ} \mathrm{C}$ と $1300^{\circ} \mathrm{C}$ ではほとんど差が見られず，温度 $1300^{\circ} \mathrm{C}$ で焼成したぺ レットに拉いてわずかに各軟化温度とも低い值を示す傾 向にある.

Fig. 9 抌よび Fig. 10 は, 軟化開始温度とそれぞれ $(\mathrm{CaO}+\mathrm{MgO}) / \mathrm{SiO}_{2}$ 比およびペレットの開気孔率との 関係を示したものである. $(\mathrm{CaO}+\mathrm{MgO}) / \mathrm{SiO}_{2}$ 比との 関係では，焼成温度 $1200^{\circ} \mathrm{C}$ と $1250 \sim 1300^{\circ} \mathrm{C}$ に 2 層 別された関係が示され，後者の高温度焼成したペレット の方が軟化開始温度は高いレベルにある．軟化開始温度 は $(\mathrm{CaO}+\mathrm{MgO}) / \mathrm{SiO}_{2}$ 比が約 1.0 で極小を示した後 1.5 付近から著しく上昇する. 開気孔率との関係では $\mathrm{CaO} / \mathrm{SiO}_{2}$ 比が 0.5 と 1.5 および 2.0 に 2 層別され， 軟化開始温度は開気孔率の増大に伴つて低下寸る相関が 得られている. $\mathrm{CaO} / \mathrm{SiO}_{2}$ 比が 0.5 のペレットの軟化 開始温度は低いレベルにある.

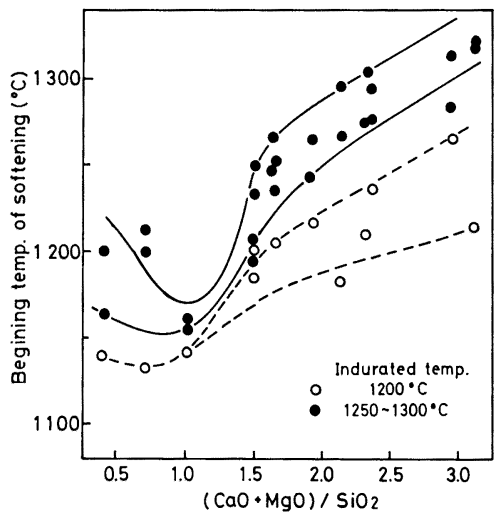

Fig. 9. Relation between beginning temp. of softening and $(\mathrm{CaO}+\mathrm{MgO}) / \mathrm{SiO}_{2}$ ratio of sampled pellets.

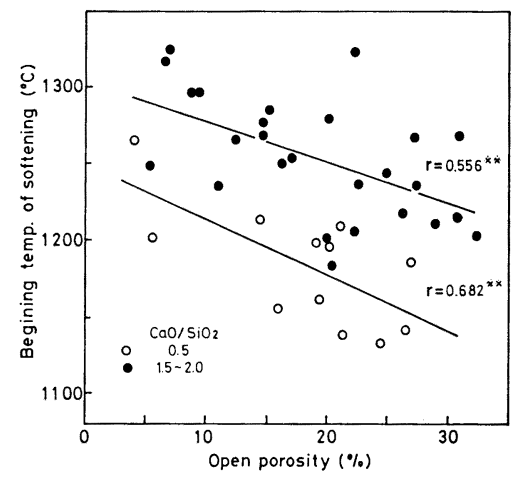

Fig. 10. Relation between beginning temp. of softening and open porosity of sampled pellets.

Fig. 11 は $60 \%$ 軟化温度と $(\mathrm{CaO}+\mathrm{MgO}) / \mathrm{SiO}_{2}$ 比 との関係を示したものである. $(\mathrm{CaO}+\mathrm{MgO}) / \mathrm{SiO}_{2}$ 比 の増加に伴つて直線的に $60 \%$ 軟化温度は上昇する相関 が得られ, 前述の Fig. 9 と闰様に焼成温度 $1200^{\circ} \mathrm{C}$ と $1250 \sim 1300^{\circ} \mathrm{C}$ とで 2 層別されるが，軟化開始温度の場 合とは逆に低温度焼成した方がより高い $60 \%$ 軟化温度 を示す.

Photo. 1 は昇温速度 $10^{\circ} \mathrm{C} / \mathrm{min}$ の条件下で単一ペレ ットによる昇温還元試験（無荷重下）において，1300 $\mathrm{C}$ で還元を停止して炉内で急冷したペレットの顕微鏡組織 を示す．供試ペレットは温度 $1300^{\circ} \mathrm{C}$ で焼成した $\mathrm{CaO}$ ， $\mathrm{SiO}_{2}$ 比が 1.5 で $\mathrm{MgO}$ 0 4\% 含有するものである.

ペレット外殼部の組織は, $\mathrm{MgO} 1 \%$ までは金属鉄の 凝集および多量のスラグ相の生成が見られるが， $\mathrm{MgO}$ $2 \%$ 以上になると金属鉄が微細化しており，またスラグ 相の生成が皃とんど観察されなくなる. ペレット中核 部・未還元層の 組織はウスタイトとスラグから成り, 


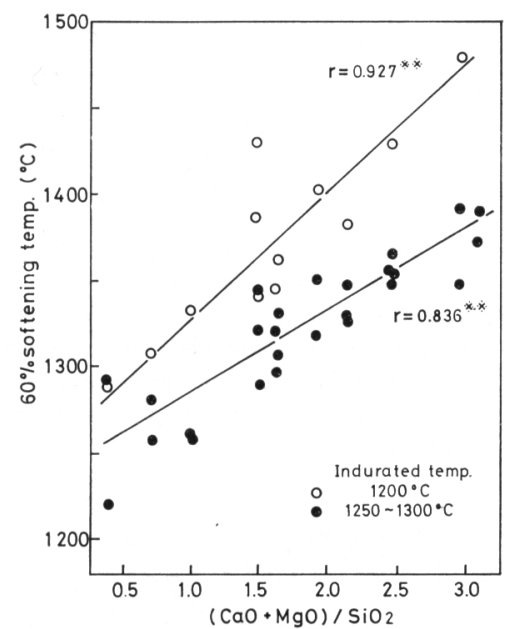

Fig. 11. Relation between 60\% softening temp. and $(\mathrm{CaO}+\mathrm{MgO}) / \mathrm{SiO}_{2}$ ratio of sampled pellets.

$\mathrm{MgO} \mathrm{1}$ \% 含有ペレットに拈いてウスタイト相の粒成長 が最も著しく，スラグの生成量は最も少なく，スラグが ペレット外殼部へ移動したものと推察される。これらの 顕徽鏡組織の変化から，所定量以上の $\mathrm{MgO}$ を添加する ことにより液相スラグの生成捻よび金属鉄の凝集が阻止 されて荷重軟化性が改善されたことが類推される。

\section{4. 実験結果の検討}

\subsection{DTA による初期液相生成温度の推定と高温性状}

ペレットの高温性状は，還元過程に拈いて主にウスタ イトとスラグとの反応により生成する液相の融点・粘性
拉よび先の生成液相量に支配され，融点沶よび粘性が高 くて液相量の少ない汪ど一般に耐軟化性は良好となるも のと考えられる。そこで各ペレットの液相生成温度を以 下に述べる方法により示差熱分析装置を用い推定した.

ペレットを $900^{\circ} \mathrm{C}$ の一定温度で $\mathrm{CO} / \mathrm{CO}_{2}: 60 / 40$ 組 成のガスを用いてウスタイト段階まで還元する。この試 料を粉砕して示差熱分析用の試料とする. 示差熱分析装 置によりアルゴン気流中で昇温速度 $10^{\circ} \mathrm{C} / \mathrm{min}$ で昇温 し，約 $1500^{\circ} \mathrm{C}$ 臬昇温後同一の速度で泠却して液相の 生成扣よび凝固に伴ら吸熱扣よび発熱曲線を求める.

示差熱曲線は昇温括よび冷却時とも， $\mathrm{CaO} / \mathrm{SiO}_{2}$ 比が 0.5 以下では 2 つの, $\mathrm{CaO} / \mathrm{SiO}_{2}$ 比が 1.5 以上では核 ぼ3つのピークを示す曲線が得られる。昇温時に和ける 初めの 1 つまたは 2 つのピークは主にスラグの, 最終の ピークは主にゥスタイトの溶解にともなら溶解熱が検出 されたものである。ペレットの昇温過程に和ける液相生 成挙動は，両端ピーク温度で評価できる。Fig. 12 はこ の両端ピーク温度を各 $\mathrm{CaO} / \mathrm{SiO}_{2}$ 比和よび $\mathrm{MgO}$ 量に 対してプロットしたものである.

$\mathrm{MgO}$ 無添加に怙いては, 初期液相の生成に対応する 吸熱ピーク温度 $\left(\mathrm{H}_{1}\right.$ 温度) は $\mathrm{CaO} / \mathrm{SiO}_{2}$ 比が 0.5 付 近で約 $1090^{\circ} \mathrm{C}$ の極小值を持ち, $\mathrm{CaO} / \mathrm{SiO}_{2}$ 比が 1.5 , 2.0 之増大するに伴つてそれぞれ $1190^{\circ} \mathrm{G}$ および 1250 ${ }^{\circ} \mathrm{C}$ 之高い值を示す. $\mathrm{MgO}$ 添加の影響は, $\mathrm{CaO} / \mathrm{SiO}_{2}$ 比が 1.5 の場合は $\mathrm{MgO} \mathrm{1}$ \% に特いてわずかに低下 を示した後さらに $\mathrm{MgO}$ 量を増加すると上昇を示す. $\mathrm{CaO} / \mathrm{SiO}_{2}$ 比が 0.5 尔よび 2.0 に拈いては $\mathrm{MgO} 2 \%$ 以上から著しくこのピーク温度が上昇する。また最終ピ

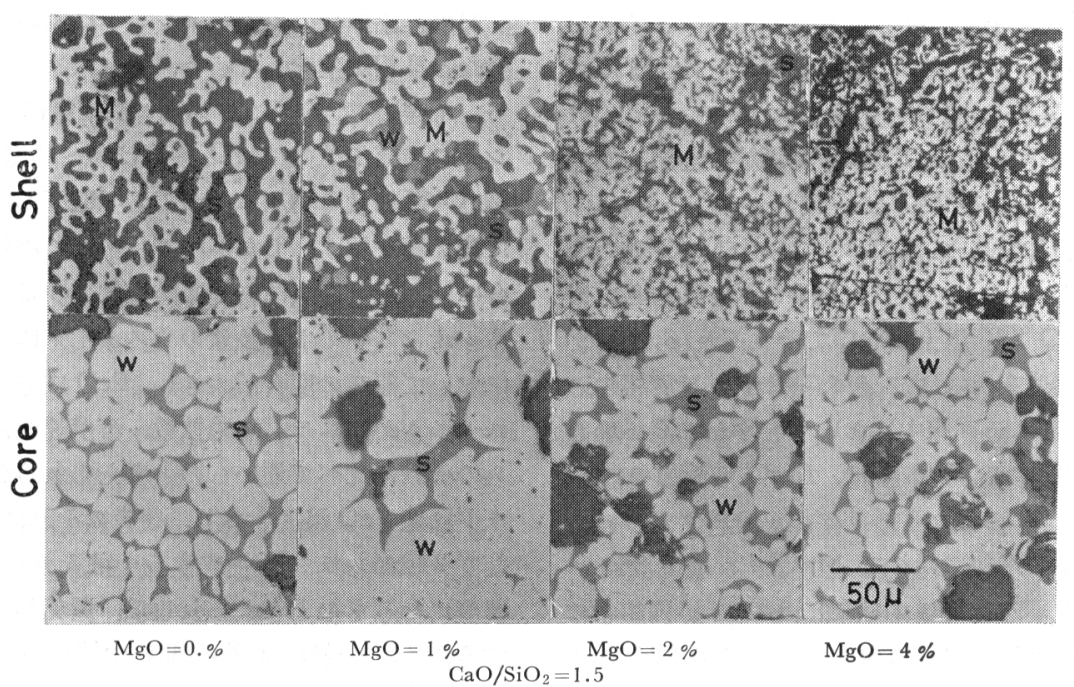

Photo. 1. Microstructures of pellets reduced up to $1300^{\circ} \mathrm{C}$ by reduction test during elevating temperature with $10^{\circ} \mathrm{C} / \mathrm{min}$ of heating rate. (w : wustite, s : slag, $\mathrm{M}$ : metalic iron) 


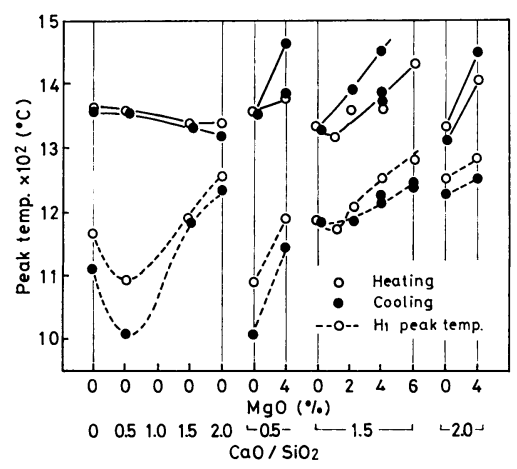

Fig. 12. Relation between exo- and endothermic peak temp. obtained from DTA curves of powder of pellets prereduced to wustite state at $900^{\circ} \mathrm{C}$, and $\mathrm{CaO} / \mathrm{SiO}_{2}$ ratio and $\mathrm{MgO}$ contents of sampled pellets (pellets indurated at $1300^{\circ} \mathrm{C}$ ).

ーク温度は, $\mathrm{MgO}$ 無添加においては $\mathrm{CaO} / \mathrm{SiO}_{2}$ 比の 増加に伴い若干低下の傾向を持ち，各 $\mathrm{CaO} / \mathrm{SiO}_{2}$ 比に 敃いての $\mathrm{MgO}$ 量の増加に伴ら変化は低温度域のピーク 温度の変化と同一の傾向にある.

Fig. 13 は温度 $1300^{\circ} \mathrm{C}$ で焼成したペレットの高温還 元率抏よび高温還元試験後の収縮率と,Fig. 14 は荷重 軟化試験より得た軟化開始温度および $60 \%$ 軟化温度と それぞれ示差熱分析曲線の低温度側吸熱ピーク温度 $\left(\mathrm{H}_{1}\right.$ 温度）との関係を示したものである。両者間にはそれぞ れ相関が見られ，したがつて高温性状は還元過程におけ る初期液相の生成温度に依存し，示差熱分析による吸熱 曲線の挙動からこの液相生成温度を推定可能である.

\section{2 還元途上ペレット中鉱物相の組成}

次に高温域還元途上に打けるペレット中ウスタイト拉 よびスラグ相の $\mathrm{MgO}$ 添加による組成変化を EPMA に よる定量分析結果から検討する. Table 1 は Photo. 1 と同一ペレットについての EPMA 分析結果を示したも のである.

ペレット外款部においては, ペレット中 $\mathrm{MgO}$ 量の増 加に伴いウスタイトおよびスラグ相中の $\mathrm{MgO}$ 含量は増 大し，特に $\mathrm{MgO} 2 \%$ 以上に拈いてそれぞれ 6.4 扎よ び $8.1 \%$ の高濃度を示しウスタイト相とスラグ相中の $\mathrm{MgO}$ 量は同等かスラグ相中においてわずかに高い場合 が多い.スラグ相中の $\mathrm{FeO}$ 量は, $\mathrm{MgO}$ 無添加では 27 \% と $8.8 \%$ の 2 つ異なるスラグ相が分析され，ヘレ ット中 $\mathrm{MgO}$ 量の増加に伴つて $\mathrm{MgO} 4 \%$ で 5.8\% 人 と低下している. ベレット中核部においても両相中の $\mathrm{MgO}$ 含量は $\mathrm{MgO}$ 添加量の増加に伴つて $0.2 \%$ から $5.3 \%$ へと増大するが，外殼部に比べて $\mathrm{MgO}$ 含有は少 ない.またスラグ相中の $\mathrm{FeO}$ 量は $\mathrm{MgO} 2 \%$ までは

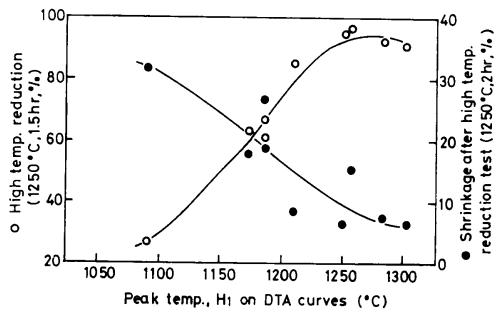

Fig. 13. Relation between reduction degree and shrinkage value by high temp. reduction test at $1250^{\circ} \mathrm{C}$, and endothermic peak temp. in the lower temp. region on DTA curves.

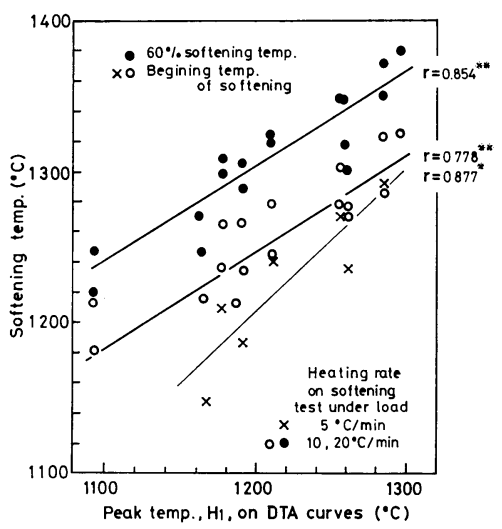

Fig. 14. Relation between softening temp. by softening test under load and endothermic peak temp. in the lower temp. region on DTA curves.

高濃度と低濃度の 2 相が分析され $\mathrm{MgO} 4 \%$ において $\mathrm{FeO} 6.5 \%$ の一相となる。

$\mathrm{MgO}$ 添加量の少ないペレットに执いて $\mathrm{FeO}$ 濃度の 異なる 2 相が生成している. これは次のように説明され る。前報19)で述べたように，焼成時に出現するマグネ シオフェライトの $\mathrm{MgO}$ 濃度は 5〜15\% と高濃度で, $\mathrm{MgO}$ 添加量の増加に伴つて若干低下して外周部におい て高い值を示す．したがつて， $\mathrm{MgO}$ 添加量の少ない場 合には，還元途上において酸化鉄は少量で偏在したマグ ネシオウスタイトと多量のウスタイトに変態し，外周部 に拈いて偏在の度合が大きい. $\mathrm{FeO}$ 成分のマグネシオウ スタイトからスラグへの拡散・溶解速度はウスタイトか らのそれに比べて遅いものと考えられるから，前者のス ラグは低 $\mathrm{FeO}$ 濃度となり，後者のそれは高 $\mathrm{FeO}$ 濃度と なり 2 相のスラグが生成する。 また外周部ほど高 $\mathrm{FeO}$ 濃度になるものと考えられるが，還元が外周部から進行 するため，一般には外款部と中核部の界面において高 $\mathrm{FeO}$ 濃度スラグが多量に生成するものと推察される.

以上述べた各相の組成と同時にその存在量も高温性状 
Table 1. EPMA analytical results of each phase in pellets reduced up to $1300^{\circ} \mathrm{C}$ by reduction test during elevating temperature*

\begin{tabular}{|c|c|c|c|c|c|c|c|c|c|c|}
\hline \multirow{2}{*}{$\begin{array}{c}\text { Aimed } \\
\mathrm{MgO} \\
(\%)\end{array}$} & \multirow{2}{*}{$\begin{array}{l}\text { Part of } \\
\text { Pellet }\end{array}$} & \multicolumn{6}{|c|}{$\mathrm{wt} \%$ as oxide } & \multirow{2}{*}{$\frac{\mathrm{CaO}}{\mathrm{SiO}_{2}}$} & \multirow{2}{*}{$\frac{\mathrm{G}+\mathrm{M}}{\mathrm{S}}$} & \multirow{2}{*}{ Phase } \\
\hline & & $\mathrm{FeO}$ & $\mathrm{CaO}$ & $\mathrm{SiO}_{2}$ & $\mathrm{Al}_{2} \mathrm{O}_{3}$ & $\mathrm{MgO}$ & Total & & & \\
\hline \multirow{2}{*}{$0 \%$} & Shell & $\begin{array}{r}27.0 \\
8.8\end{array}$ & $\begin{array}{l}37.5 \\
54.3\end{array}$ & $\begin{array}{l}30.6 \\
34.2\end{array}$ & $\begin{array}{l}0.4 \\
0.7\end{array}$ & $\begin{array}{l}1.3 \\
2.1\end{array}$ & $\begin{array}{r}96.8 \\
100.1\end{array}$ & $\begin{array}{l}1.22 \\
1.59\end{array}$ & $\begin{array}{l}1.27 \\
1.65\end{array}$ & $\begin{array}{l}\text { SL } \\
\text { SL }\end{array}$ \\
\hline & Core & $\begin{array}{r}96.4 \\
3.0 \\
14.2\end{array}$ & $\begin{array}{r}0.5 \\
62.6 \\
50.3\end{array}$ & $\begin{array}{r}0.2 \\
34.0 \\
33.3\end{array}$ & $\begin{array}{l}0.8 \\
0.4 \\
0.3\end{array}$ & $\begin{array}{l}0.6 \\
0.2 \\
0.3\end{array}$ & $\begin{array}{r}98.5 \\
100.2 \\
98.4\end{array}$ & $\begin{array}{l}1.84 \\
1.51\end{array}$ & $\begin{array}{l}1.85 \\
1.52\end{array}$ & $\begin{array}{l}\text { W } \\
\text { SL } \\
\text { SL }\end{array}$ \\
\hline \multirow{2}{*}{$1 \%$} & Shell & $\begin{array}{r}89.8 \\
8.8\end{array}$ & $\begin{array}{r}0.8 \\
52.5\end{array}$ & $\begin{array}{r}0.3 \\
33.5\end{array}$ & $\begin{array}{l}0.9 \\
0.4\end{array}$ & $\begin{array}{l}2.1 \\
2.1\end{array}$ & $\begin{array}{l}93.9 \\
99.1\end{array}$ & 1.57 & 1.61 & $\begin{array}{l}\text { W } \\
\text { SL }\end{array}$ \\
\hline & Core & $\begin{array}{r}89.9 \\
14.4 \\
9.1\end{array}$ & $\begin{array}{r}0.5 \\
44.9 \\
52.8\end{array}$ & $\begin{array}{r}0.2 \\
33.1 \\
33.7\end{array}$ & $\begin{array}{l}0.5 \\
3.3 \\
0.2\end{array}$ & $\begin{array}{l}1.8 \\
3.3 \\
1.6\end{array}$ & $\begin{array}{l}92.9 \\
99.0 \\
97.4\end{array}$ & $\begin{array}{l}1.35 \\
1.56\end{array}$ & $\begin{array}{l}1.46 \\
1.61\end{array}$ & $\begin{array}{l}\text { W } \\
\text { SL } \\
\text { SL }\end{array}$ \\
\hline \multirow{2}{*}{$2 \%$} & Shell & $\begin{array}{r}86.0 \\
7.9\end{array}$ & $\begin{array}{r}0.7 \\
46.5\end{array}$ & $\begin{array}{r}0.2 \\
35.0\end{array}$ & $\begin{array}{l}0.8 \\
0.2\end{array}$ & $\begin{array}{l}6.4 \\
8.1\end{array}$ & $\begin{array}{l}94.1 \\
97.7\end{array}$ & 1.32 & 1.56 & $\begin{array}{l}\mathrm{W} \\
\mathrm{SL}\end{array}$ \\
\hline & Core & $\begin{array}{r}90.7 \\
8.8 \\
12.9\end{array}$ & $\begin{array}{r}0.5 \\
51.4 \\
45.8\end{array}$ & $\begin{array}{r}0.2 \\
33.1 \\
33.3\end{array}$ & $\begin{array}{l}0.7 \\
0.3 \\
0.3\end{array}$ & $\begin{array}{l}2.2 \\
2.1 \\
3.9\end{array}$ & $\begin{array}{l}94.3 \\
95.7 \\
96.2\end{array}$ & $\begin{array}{l}1.55 \\
1.37\end{array}$ & $\begin{array}{l}1.62 \\
1.49\end{array}$ & $\begin{array}{l}\text { W } \\
\text { SL } \\
\text { SL }\end{array}$ \\
\hline \multirow{2}{*}{$4 \%$} & Shell & $\begin{array}{r}83.5 \\
5.8\end{array}$ & $\begin{array}{r}0.7 \\
46.6\end{array}$ & $\begin{array}{r}0.2 \\
35.1\end{array}$ & $\begin{array}{l}0.7 \\
0.3\end{array}$ & $\begin{array}{l}9.5 \\
9.0\end{array}$ & $\begin{array}{l}94.6 \\
96.8\end{array}$ & 1.33 & 1.58 & $\begin{array}{l}\mathrm{W} \\
\mathrm{SL}\end{array}$ \\
\hline & Core & $\begin{array}{r}87.6 \\
6.5\end{array}$ & $\begin{array}{r}0.4 \\
52.7\end{array}$ & $\begin{array}{r}0.2 \\
33.7\end{array}$ & $\begin{array}{l}0.7 \\
0.3\end{array}$ & $\begin{array}{l}5.3 \\
3.2\end{array}$ & $\begin{array}{l}94.2 \\
96.4\end{array}$ & 1.56 & 1.66 & $\begin{array}{l}\text { W } \\
\text { SL }\end{array}$ \\
\hline
\end{tabular}

$(\mathrm{C}+\mathrm{M}) / \mathrm{S}:(\mathrm{CaO}+\mathrm{MgO}) / \mathrm{SiO}_{2} \mathrm{~W}:$ Wustite, $\mathrm{SL}: \mathrm{Slag}, *$ Heating rate $=10^{\circ} \mathrm{C} / \mathrm{min}$.

へ影響する因子となる. 各相の存在量を以下方法で算出 した. 各相は Table 1 に示す組成のものしか存在しな いものと仮定し，この組成とペレットの化学分析值とを 基に $\mathrm{Fe}, \mathrm{CaO}$ および $\mathrm{MgO}$ の成分について二元または 三元一次の連立方程式を解いて各相の存在量をペレット 外殼部と中核部それぞれについて算出する。ペレット全 体としての各相の存在量を求めるため外款部と中核部と の割合を次式より算出する.

$$
\frac{\begin{array}{l}
(\text { 外殼部 } \mathrm{FeO} \% \times A+\text { 中核部 } \mathrm{FeO} \% \times B) \\
\times 0.01 \times(\mathrm{O} / \mathrm{FeO})
\end{array}}{\text { 焼成ペレット中 } \mathrm{O}_{2} \%}=1-\frac{\text { 還元率 }}{100}
$$

ここで, $A(\%)$ は外殼部の割合， $B(\%)=100-A$ は中 核部の割合である. この $A, B$ の值を両部について求め た各相の存在量にそれぞれ乗することにより各相の存在 量が求まる. Table 2 に各相の存在量と外款部拈よび中 核部の割合の算出結果を示す.

外殼部スラグ相は $\mathrm{MgO}$ 量の増加に伴いその存在量を 増大するが，前述の EPMA による組成分析結果から $\mathrm{MgO}$ 含有量が多くて $\mathrm{FeO}$ 含有量の少ないスラグ相と なる. また，中核部スラグ相は逆にその存在量の減少を 示し, ペレット中 $\mathrm{MgO} 1 \%$ までは $\mathrm{FeO} 14.2 \%$ のス ラグが大半を, $\mathrm{MgO} 2 \%$ では $\mathrm{FeO} 12.9 \%$ スラグが約
半量を占め, さらに $\mathrm{MgO} 4 \%$ では $\mathrm{FeO} 6.5 \%$ の低 $\mathrm{FeO}$ 量のスラグ相のみの存在となる.

以上の還元途上で生成する液相の融点, 各鉱物相の組 成およびその存在量に関する検討から, ペレットの高温 性状改善におよぼす $\mathrm{MgO}$ 成分の作用は次のように説明 される.すなわち，昇温還元過程においてウスタイトと スラグ相との反応により $\mathrm{FeO}$ 成分がスラグ相へ溶解す ることによりこのスラグ相の融点を下げて初期液相が生 成する，ウスタイト相中へ $\mathrm{MgO}$ が固溶することにより ウスタイト中の $\mathrm{Fe}^{2+}$ が安定して $\mathrm{MgO}$ を固溶しないウ スタイトに比べてスラグ相中への $\mathrm{FeO}$ の溶解量が減少 するものと考えられる. したがつて， $\mathrm{MgO}$ のウスタイ ト相への拡散によるウスタイトの均一化の速度执よびウ スタイト相中の $\mathrm{MgO}$ 濃度が, 初期液相生成温度および その生成量を支配し， $\mathrm{MgO}$ 添加量の多いペレットほど マグネシオフェライトの生成量が多いことから $\mathrm{MgO}$ の ウスタイトへの拡散はすみやかに進行する. また昇温速 度の遅いほどヘンレットに液相が生成する以前にこのウ スタイトの均一化が完了するため, スラグ相への $\mathrm{FeO}$ 溶解量が減少する．このように，還元過程における初期 液相の生成温度を高めさらにはその生成量を減少する作 用を $\mathrm{MgO}$ 成分が有することにより，高温性状が改善す 
Table 2. Calcurated existing amounts of both layers and each phase in pellets reduced up to $1300^{\circ} \mathrm{C}$ by reduction test during elevating temperature*.

\begin{tabular}{l|c|c|c|c}
\hline \multirow{2}{*}{ Layer of Phase } & \multicolumn{4}{|c}{ MgO in pellet (\%) } \\
\cline { 2 - 5 } & $0 \sim$ & 1.0 & 2.0 & 4.0 \\
\hline Shell (\%) & 39.7 & 69.9 & 70.3 & 88.1 \\
Core (\%) & 60.3 & 30.1 & 29.7 & 11.9 \\
Thickness of & 15.5 & 33.0 & 33.3 & 50.8 \\
shell (\%) & & & & \\
\hline Iron (\%) & 32.8 & 27.8 & 45.8 & 43.7 \\
Wustite (\%) & 51.3 & 59.5 & 39.0 & 41.4 \\
Slag (\%) & 4.4 & 8.7 & 11.5 & 13.6 \\
in Shell & $(27.0)$ & $(8.8)$ & $(7.9)$ & $(5.8)$ \\
Slag (\%) & $(8.5$ & & & \\
in core & 9.0 & 4.0 & 1.9 & 1.4 \\
& $(14.2)$ & $(14.4)$ & $(12.9)$ & $(6.5)$ \\
tr. & tr. & 1.8 & \\
\hline Reduction (\%) & 56.6 & 54.2 & 68.4 & 67.9 \\
\hline
\end{tabular}

$*$ : Heating rate $=10^{\circ} \mathrm{C} / \mathrm{min} . \quad(\quad): \mathrm{FeO}$ in slag

\section{るものと考えられる。}

\section{3 焼成ペレット中鉱物相の荷重化性状}

$\mathrm{MgO}$ 添加による高温性状の変化は, 焼成ペレット中 に出現する鉱物相とも密接なる関係にあるものと考えら れる.Fig. 15 は，前報19)の $\mathrm{MgO}$ 添加自溶性ペレット 中の鉱物組織の分類に基づき，各鉱物単一の荷重軟化挙 動を収縮率-温度曲線で示したものである・各供試合成鉱 物の作成条件を Table 3 に示す. 荷重軟化試験方法は 既報18) と同一であるので省略する。

マグネシオフェライトの荷重軟化性は高塩基度スラグ (D)に次いで良好である. カルシウムフェライト $(\mathrm{C})$ の 荷重軟化性は $\mathrm{MgO}$ を含有することにより 1130 $1340^{\circ} \mathrm{C}$ の温度域において大きく改善されるが，低塩基 度スラグ $(\mathrm{A})$ のそれは逆に $\mathrm{MgO}$ を含有することにより 劣化する. $\mathrm{MgO}$ 約 $2 \%$ 含有する中塩基度スラグ (B) は低塩基度スラグ $(\mathrm{A})$ よりわずかに荷重軟化性は良好で あるが，温度 $1200^{\circ} \mathrm{C}$ 以上から急激に軟化し，約 1260 ${ }^{\circ} \mathrm{C}$ で溶融する。

Fig. 16 は焼成ペレット中の各鉱物相の存在量拉よび 開気孔率と，ペレットの高温性状值として昇温速度 10 ${ }^{\circ} \mathrm{C} / \mathrm{min}$ の条件下での荷重軟化試験より求めた軟化開始 温度および $60 \%$ 軟化温度さらには高温還元率を対比し て示したものである。マグネシオフェライトまたはカル シウムフェライトの生成量が多くなるほぼ，各高温性状 值が良好となる傾向が示され，またマグネシオフェライ

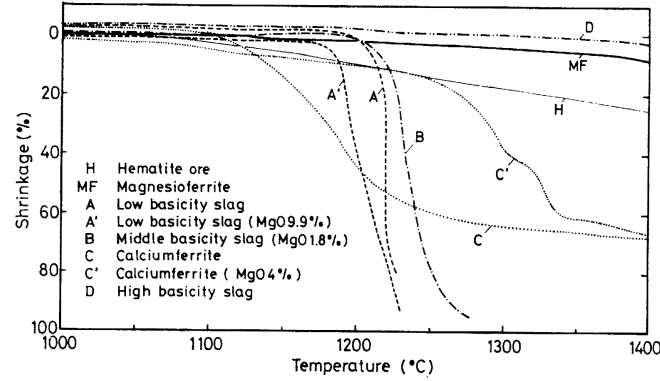

Fig. 15. Shrinkage curves of hematite ore and synthesized minerals.

Table 3. Synthesized conditions of sampled minerals.

\begin{tabular}{|c|c|c|c|c|c|c|c|}
\hline \multirow{2}{*}{$\begin{array}{l}\text { Min- } \\
\text { eral }\end{array}$} & \multicolumn{5}{|c|}{ Chemical reagent (wt $\%)$} & \multicolumn{2}{|c|}{ Synthesized } \\
\hline & $\mathrm{Fe}_{2} \mathrm{O}_{3}$ & $\mathrm{CaO}$ & $\mathrm{SiO}_{2}$ & $\mathrm{MgO}$ & $\begin{array}{l}\mathrm{CaO} / \\
\mathrm{SiO}_{2}\end{array}$ & ${ }^{\text {temp. }}$. & $\begin{array}{c}\text { time } \\
h\end{array}$ \\
\hline $\mathbf{H}$ & 99.8 & & & & & 1300 & 5 \\
\hline $\mathrm{MF}$ & 90.0 & & & 10.0 & & 1300 & 5 \\
\hline A & 30.2 & 24.3 & 45.5 & & 0.53 & 1300 & 5 \\
\hline $\mathrm{A}^{\prime}$ & 24.1 & 22.5 & 43.5 & 9.9 & 0.52 & 1300 & 5 \\
\hline B & 15.3 & 41.7 & 41.2 & 1.8 & 1.01 & 1300 & 5 \\
\hline $\bar{C}$ & 78.4 & 18.7 & 2.9 & & & 1220 & 5 \\
\hline $\mathrm{C}^{\prime}$ & 75.3 & 17.9 & 2.8 & 4.0 & & 1220 & 5 \\
\hline D & 24.3 & 43.5 & 31.7 & & 1.37 & 1300 & 0.17 \\
\hline
\end{tabular}

$\mathrm{H}:$ Hematite ore, MF : Magnesioferrite, $\mathrm{A}, \mathrm{A}^{\prime}$ : Low hasicity slag, B : Middle basicity slag, C, $\mathrm{C}^{\prime}$ : Calciumferrite, D : High basicity slag

トが生成せず低塩基度スラグまたは中塩基度スラグの生 成が増大する $\mathrm{CaO} / \mathrm{SiO}_{2}$ 比が 0.5 および 1.5 で $\mathrm{MgO}$ $1 \%$ に拈いて，特に高温還元率が 極小の值を示してい る.このように，焼成ペレット中に荷重軟化性の良好な るマグネシオフェライトまたはカルシウムフェライトの 生成量が多いほど高温性状も良好となる，単一鉱物の荷 重軟化性とほぼ対応した関係が得られている.

\section{5. 結言}

塩基度 $0.5,1.5,2.0$ の組成で $\mathrm{MgO}$ 含有量 $0 \sim 4 \%$ （８％）の範囲で種々調製した $10 \mathrm{~mm} \phi$ のペレットを実 験室的に製造して各種治金性状に拈よぼす $\mathrm{MgO}$ 添加の 影響を明らかにした。得られた結果は次の通りである。

(1) 還元率は $\mathrm{MgO}$ の添加により $\mathrm{CaO} / \mathrm{SiO}_{2}$ 比が 0.5 のペレットでは増大し, $\mathrm{CaO} / \mathrm{SiO}_{2}$ 比が 1.5 およ び 2.0 のペレットでは焼成温度 $1200^{\circ} \mathrm{C}$ の場合は増大 するが焼成温度 $1250 \sim 1300^{\circ} \mathrm{C}$ の場合は変化がないか 低下する。

(2) ふくれ指数は $\mathrm{MgO}$ の添加により， $\mathrm{CaO} / \mathrm{SiO}_{2}$ 比が 0.5 のペレットでは $\mathrm{MgO}$ 1〜2\% において 20〜 $45 \%$ と高い值を示す場合が多く, $\mathrm{MgO} 4 \%$ に打いて初 


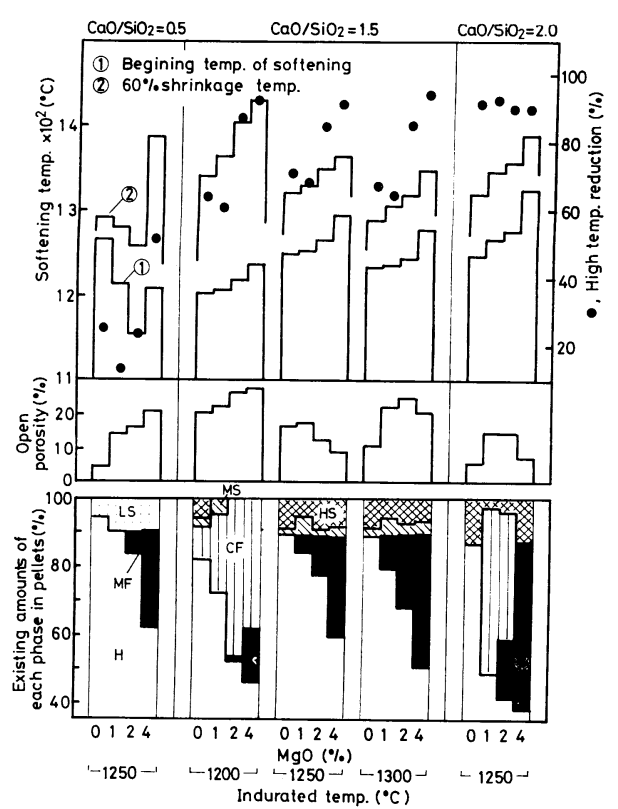

Fig. 16. Corresponding relations between high temperature properties, and open porosity and existing amounts of each mineral phase in indurated pellets. $(\mathrm{H}$ : Hematite, MF : Magnesioferrite, LS : Low basicity slag, CF : Calciumferrite MS : Middle basicity slag, HS : High basicity slag)

めて $10 \sim 15 \%$ へと低下する. $\mathrm{CaO} / \mathrm{SiO}_{2}$ 比が 1.5 の ペレットでは低下を示し, $\mathrm{CaO} / \mathrm{SiO}_{2}$ 比が 2.0 のペレッ トでは $\mathrm{CaO} / \mathrm{SiO}_{2}$ 比が 0.5 のペレットと同様に $\mathrm{MgO}$ 1〜2\% でわずかに高くなる傾向にあるが，ふくれ指数 は 10\% 以下と低い.

（3）荷重軟化性状は $\mathrm{MgO}$ の添加により改善される 傾向にあるが，昇温速度により $\mathrm{MgO}$ 添加の効果は異な る. 昇温速度 $5^{\circ} \mathrm{C} / \mathrm{min}$ に打いては $\mathrm{MgO}$ 添加量の増大 に伴つて荷重軟化性状は良好となるが, 昇温速度 $10 \sim 20$ ${ }^{\circ} \mathrm{C} / \mathrm{min}$ に括いては $\mathrm{CaO} / \mathrm{SiO}_{2}$ 比が 0.5 では $\mathrm{MgO} 4$ $\%$ 以上, $\mathrm{CaO} / \mathrm{SiO}_{2}$ 比が 1.5 では $\mathrm{MgO} 2 \%$ 以上含 有して初めて顕著に改善される.

焼成ペレット中に出現する鉱物相の荷重軟化挙動の測 定から， $\mathrm{MgO}$ を所定量含有することにより荷重軟化性 状の良好なマグネシオフェライトまたは $\mathrm{MgO}$ を含有し たカルシウムフェライトの生成がなされて高温性状が改 善されたものと推察される. マグネシオフェライトの生 成が少なく, 荷重軟化性の悪い低塩基度スラグおよび中 塩基度スラグを多く生成したペレットにおいて特に高温 還元率は低い値を示す.

\section{交献}

1) 藤田勇雄, 小野田守, 竹中芳通: 水曜会誌, 18 (1977) p. 584

2) I. Fujita, $M$. Onoda, $O$. Tsuchiya, $O$. SAHeki, $K$. TAguchi, and $I$. Nishida: Agglomeration '77, Proc. International Symposium on Agglomeration, 2 (1977), p. 803

3 ) K. E. Merklin and F. D. Devaney: Soc. Min. Eng., AIME Trans. 254 (1960), p. 266

4 ) $G . S$. Vasil'ev, G. G. Efimenko, D. $A$. Kovalev, and $E$. $I$. Sulimenko: Steel in USSR, (1971), p. 415

5 ) N. I. Perminov, I. A. Kopyrin, Yu. M. Borts, and L. S. Grabko: Steel in USSR, (1972), p. 415

6 ) G. G. Efimenko, K. I. Kotov, I. I. Pyshlevich, A. M. ZhaK, and A. I. Gurin: Steel in USSR, (1972), p. 335

7) $V . P$. Bratchenk, L. Ya. Gavryuk, $N . M$. Kryukov, $A$. $L$. Galatonov, and $F$. $A$. YUSHIN: Steel in USSR, (1972)

8 ) I. A. Kopyrin and $I . F$. Graur: Izv. VUZ chern. Met., 6 (1974) p. 41

9 ) $G$. Thaning: LKAB NEWS, Special Report. Oct. 1974

10) J. C. Nigro, R. K. ZAnL, and C. Prasky: Soc. Min. Eng., AIME Trans., 254 (1973), p. 328

11) B. Björkvall and $P$. A. Ilmoni : Rev. Mét., (1976) 6, p. 583

12) P. Barnaba: Iron making Proceedings, AIME, 38 (1978), p. 53

13) D. E. Morin, F. Gappuccitti, C. $A$. Pickles, $H . U$. Ross, and $T . R$. Meadowcroft: Iron Making Proceedings, AIME, 38 (1978), p. 69

14) 土屋 敒, 小野田守, 藤田勇雄：鉄と鋼，65 (1973) 3，p. 349

15）杉山健, 城内章治, 土屋 脩, 小野田守, 藤田 勇雄：鉄と鋼，65（1979）4，S 100

16) 杉山 健, 城内章治, 土屋 佾, 小野田守, 藤田 勇雄：鉄と鋼，65（1979） 11，S S 570

17) 土屋 脩, 大槻 健, 杉山 健, 小野田守, 藤田 勇雄：鉄と鋼，66（1980) 8, p. 1057

18) 土屋 䀺, 大㚘 健, 杉山 健, 小野田守, 藤田 勇雄：鉄と鋼，66（1980）9, p. 1297

19) 土屋 脩, 杉山健, 小野田守, 藤田勇雄：鉄之 鋼，66（1980） 13，p. 1830

20) E. F. Osborn and A. Muan: "Phase Equilibria among Oxides in Steelmaking”, The Pensylvania state Univ., (1964)

21）松野二三郎：鉄と鋼，64（1978） 10，p. 1499

22）佐々木稔，榎戸恒夫，近藤真一，中沢孝夫：鉄と 鋼，59（1973）9，p. 1209 